\title{
Patterns of sperm allocation across successive ejaculates in four species of voles (Microtus)*
}

\author{
J. D. Pierce, Jr, B. Ferguson, A. L. Salo, D. K. Sawrey, L. E. Shapiro, \\ S. A. Taylor and D. A. Dewsbury \\ Department of Psychology, University of Florida, Gainesville, FL 32611, USA
}

\begin{abstract}
Summary. This study was designed to determine testes masses, total number of spermatozoa ejaculated per copulatory episode, and the pattern of sperm numbers in successive ejaculates in prairie voles (Microtus ochrogaster), montane voles $(M$. montanus), pine voles ( $M$. pinetorum), and meadow voles ( $M$. pennsylvanicus). Prairie voles displayed mean totals of 2.7 ejaculations and $30.5 \times 10^{6}$ spermatozoa before reaching a satiety criterion; montane voles 3.4 ejaculations and $19.0 \times 10^{6}$ spermatozoa, pine voles 2.4 ejaculations and $3.3 \times 10^{6}$ spermatozoa, and meadow voles $2 \cdot 5$ ejaculations and $25.5 \times 10^{6}$ spermatozoa. In all species the number of spermatozoa decreased in successive ejaculates. Significant species differences were noted for the total number of spermatozoa ejaculated and number of spermatozoa ejaculated in each of the first 3 ejaculates. Species differences also were noted for testes mass, with meadow voles having the largest testes and pine voles having the smallest. These data can be compared to similar data on laboratory rats and deer mice and related to recent theory regarding sperm numbers, testes sizes, and mating systems. In general, the species with large testes appear to ejaculate more spermatozoa. The significance of species differences in testes mass and total sperm numbers remains unclear, but may relate to the occurrence of multiple mating by females during a single receptive period.
\end{abstract}

Keyrords: Microtus; spermatozoa; mating systems; copulation

\section{Introduction}

Recent theory has emerged in which testes sizes and sperm allocation patterns are linked to each other and to interspecific variations in mating systems (Short, 1979; Parker, 1984; Kenagy \& Trombulak, 1986; Harvey \& May, 1989). Further development and testing of this integrative theory will depend on the availability of an adequate database of comparative information. Data on the constituents of successive ejaculates are available for numerous diverse species, such as rabbits (Adams \& Singh, 1981), turkeys (Bakst \& Cecil, 1981), horses (Squires et al., 1979), and laboratory rats (Toner \& Adler, 1985; Austin \& Dewsbury, 1986). Information on testes sizes also is available for various species (e.g. Harvey \& Harcourt, 1984). However, evolutionary pressures are revealed most clearly when data from groups of closely related species, rather than arbitrary samples of diverse species, can be compared (King, 1970). In particular, there is a need for collecting information from the same species on these two variables. The present research was designed to aid development of such a database for the muroid rodents, a group that is ideal for such analyses because they display considerable variability and most species generally adapt well to the laboratory environment.

\footnotetext{
* Reprint requests to Professor D. A. Dewsbury.
} 
The issue of ejaculate allocation can be broken down into two related, but separate, questions. The first concerns the total number of spermatozoa available; the second deals with the allocation of spermatozoa to successive ejaculates. Sperm numbers have come to be interpreted in relation to sperm competition, the competition between the ejaculates of different males mating with a single female within a single oestrous period (see Parker, 1970). Short (1979) initiated the current interest in the problem by proposing a relationship among testes size, sperm numbers, and mating systems. Short argued that "in promiscuous mating systems; if several males are allowed to copulate with one female, gamete selection will favor the male who deposits the most spermatozoa" (Short, 1979, p. 155), a phenomenon termed 'sperm loading' (Parker, 1984; Dickinson, 1986). By this hypothesis, sperm numbers are related to testes sizes and males in species with promiscuous mating systems should have larger testes than those in species in which females generally mate with just one male.

The hypothesis linking testes sizes to mating system has received appreciable support (Short, 1979; Harcourt et al., 1981; Clutton-Brock et al., 1982; Harvey \& Harcourt, 1984; Kenagy \& Trombulak, 1986), but there is little information supporting the important implicit assumption that across species testes sizes are closely related to the numbers of available spermatozoa. Although there is some support for this relationship within species (Lino, 1972; Abdou et al., 1978), some data are contradictory (Carter, A. P., et al., 1980). Moller (1988a) has reviewed evidence for 25 primate species and noted a strong positive correlation between testes size and several measures of ejaculate quality, including ejaculate volume, sperm count, and sperm motility. A review of 33 bird species likewise revealed a relationship among testes size, ejaculate quality, and sperm competition (Moller, 1988b).

It can be argued that a more appropriate measure of ejaculate quality is sperm numbers across sequential ejaculates (see Moller, 1988a), a measure which would more clearly delineate the links both of testes sizes and sperm numbers to mating systems. Moller (1988b) noted for birds that sperm numbers per ejaculate varied with the degree of sperm competition. A literature review of data for 9 mammalian species from several taxa suggested that animals with large testes produced large numbers of spermatozoa per ejaculate (Moller, 1989). Sperm numbers across successive ejaculates were measured in the present study.

The second question concerns the allocation of spermatozoa across successive ejaculates. Parker (1984) distinguished between 'S patterns', in which males deposit a single, large ejaculate, and 'M patterns', in which males deposit smaller, multiple ejaculates. Species with monogamous mating systems might be expected to evolve toward the $S$ pattern, as sexual activity tends to be reduced (Kleiman, 1977). In species with polygamy or promiscuity, however, the $\mathbf{M}$ pattern might be expected. This permits facultative alterations in allocation patterns among females as a function of female availability (Lanier et al., 1979; Lott, 1981; Dewsbury, 1982; Gibson \& Jewell, 1982; Parker, 1984). The more predictable it is that multiple mates will be available, the flatter should be the functions of sperm counts over successive ejaculates (see Markow, 1985). When females mate with several males, selection appears generally to favour a pattern in which males deliver a large first ejaculate and decrease the investment in successive ejaculates (Svard \& Wiklund, 1986). This is a common vertebrate pattern (see Austin \& Dewsbury, 1986) and may have evolved because the predictability of future matings is not always great. From this logic, it would appear that monogamous species should have fewer ejaculates and that the decrement in sperm counts over successive ejaculates might be sharper than in more polygamous species. The fertilizing life of spermatozoa in the female reproductive tract and duration of oestrus also appear to be important factors in the evolution of sperm allocation patterns (Parker, 1984).

Voles of the genus Microtus adapt well to the laboratory and are ideal subjects, partly because much is known about their reproductive patterns (Carter et al., 1986; Dewsbury, 1988). Females of all microtine species appear to be induced ovulators (Sawrey \& Dewsbury, 1985). Prairie voles, Microtus ochrogaster, appear generally to be monogamous in the field (Getz et al., 1981; Getz \& Hofmann, 1986), as do pine voles, $M$. pinetorum (FitzGerald \& Madison, 1983). In contrast, the mating systems of montane voles, $M$. montanus (Jannett, 1980, 1982), and meadow voles, $M$. 
pennsylvanicus (Madison, 1980a, b), appear to be generally polygamous. Because the characteristics of their ejaculates might be expected to differ, these 4 species were studied using methods identical to those used with two previous species, laboratory rats (Austin \& Dewsbury, 1986) and deer mice (Dewsbury \& Sawrey, 1984). Testes sizes also were determined.

\section{Materials and Methods}

Animals. Animals used for sperm counts were 13 male and 35 female prairie voles (Microtus ochrogaster), from the colony long maintained at the University of Florida (Gray \& Dewsbury, 1973), 18 male and 62 female montane voles (M. montanus), from a similar colony (Dewsbury, 1973), 13 male and 31 female pine voles (M. pinetorum), and 18 male and 45 female meadow voles ( $M$. pennsylvanicus), from more recently established colonies. After collection of data on sperm counts but before collection of data on testes masses, the older prairie and montane vole colonies were replaced by newer colonies. Therefore, measures of testes mass were taken from 12 male montane voles and 13 male prairie voles from more recently established populations (see Carter, C. S., et al., 1980; Rowsemitt et al., 1982) and from 15 male pine and 17 male meadow voles from the current colonies. All animals were sexually mature and ranged from 80 to 200 days of age. They were housed in polycarbonate cages measuring $29 \times 19 \times 13 \mathrm{~cm}$ or $48 \times 27 \times 13 \mathrm{~cm}$. Animals were fed Purina rabbit chow and had free access to water. Wood shavings were used as bedding. A reversed 16-h light/8-h dark photoperiod of white fluorescent light with lights on at 20:00 h was used. Animals used in the sperm count study were sexually experienced, having served in previous experiments. Those in the study of testes mass were not known to have mated.

Behavioural testing. Each male received one test in which he was permitted to copulate for one ejaculation with each of a series of receptive females and the spermatozoa delivered to each female were counted. Females were brought into behavioural oestrus with an intramuscular injection of $0.06 \mathrm{mg}$ oestradiol benzoate $72 \mathrm{~h}$ before testing. Tests were conducted in a $48 \times 27 \times 13 \mathrm{~cm}$ cage in red light during the dark phase of the photoperiod. Males were permitted $15 \mathrm{~min}$ to habituate to the cage before the first female was introduced. If a male failed to copulate within $20 \mathrm{~min}$, the female was removed and replaced with another. Once an ejaculation occurred (see Dewsbury, 1973; Gray \& Dewsbury, 1973) the female was removed and a new female was introduced. The procedure was repeated until the male reached an arbitrary satiety criterion of $30 \mathrm{~min}$ with no copulations or $1 \mathrm{~h}$ without ejaculation, when the test was terminated.

Sperm counts. Females that received ejaculates were kept in their home cages for 15-20 min and then killed by cervical dislocation. Each was placed ventrum up and the abdomen was opened to expose the reproductive organs. Haemostats were used to isolate the reproductive tracts at the vaginal orifice, and each of the termini of the uterine horns. The whole tract was then removed and placed into a plastic dish with approximately $5-10 \mathrm{ml}$ distilled water. A total of $40 \mathrm{ml}$ water was used for the experimental procedures, of which $5-10 \mathrm{ml}$ were used for extraction and the remainder to flush the dish into a storage vial. Scissors and a scalpel were used to open and scrape the contents from the whole tract. The 5-10 $\mathrm{ml}$ water and fluids from within the reproductive tract were then poured into a container with approximately $0.2 \mathrm{~g}$ EDTA salt (an anti-clumping agent). The whole $40 \mathrm{ml}$ was then agitated until the contents were in suspension. Either sperm counts were done at this time or the vials were refrigerated until later. If counts were done at a later time, vials were first allowed to reach room temperature, then agitated on a stirring hot plate for $5 \mathrm{~min}$. Samples were then taken for counting.

Two samples were withdrawn from a single vial and placed on a haemocytometer to count the number of spermatozoa. The mean of these two samples was converted $\left(\times 0.044 \times 10^{6}\right)$ to provide a single estimate of the number of spermatozoa for that ejaculate.

Testes weights. Each male vole was killed by cervical dislocation and the intact whole body mass was measured on a balance with a precision of $0.01 \mathrm{~g}$. The body was then opened by abdominal incision with dissecting scissors and the testes removed. The testes were cleaned of any fatty or connective tissue, rinsed with distilled water, and placed on a moist paper towel awaiting weighing. Testes were weighed within $5 \mathrm{~min}$ of extirpation and remained moist. The precision was $0.0001 \mathrm{~g}$.

\section{Results}

\section{Copulatory behaviour and sperm counts}

Data on copulatory behaviour and sperm counts are presented in Table 1. Montane voles reached a mean of 3.4 (range $1-7$ ), prairie voles 2.7 (range 2-3), pine voles 2.4 (range 1-4), and meadow voles $2 \cdot 5$ (range $1-6$ ) ejaculations. 
Table 1. Sperm counts for successive ejaculates in 4 species of voles

\begin{tabular}{|c|c|c|c|c|c|}
\hline Measure & $\begin{array}{c}\text { Prairie } \\
\text { voles }\end{array}$ & $\begin{array}{l}\text { Pine } \\
\text { voles }\end{array}$ & $\begin{array}{c}\text { Montane } \\
\text { voles }\end{array}$ & $\begin{array}{l}\text { Meadow } \\
\text { voles }\end{array}$ & $\begin{array}{l}\text { Kruskal- } \\
\text { Wallis } \\
\text { ANOVA }\end{array}$ \\
\hline No. of ejaculations & $\begin{array}{c}2 \cdot 7 \\
( \pm 0 \cdot 1)\end{array}$ & $\begin{array}{c}2.4 \\
( \pm 0.3)\end{array}$ & $\begin{array}{c}3 \cdot 4 \\
( \pm 0 \cdot 3)\end{array}$ & $\begin{array}{c}2.5 \\
( \pm 0.4)\end{array}$ & 6.65 \\
\hline \multicolumn{6}{|l|}{ Sperm no. $\left(\times 10^{-6}\right)$} \\
\hline Total & $\begin{array}{c}30 \cdot 5^{\mathrm{a}} \\
( \pm 6 \cdot 7) \\
\mathrm{N}=13\end{array}$ & $\begin{array}{r}3 \cdot 3^{b} \\
( \pm 0 \cdot 8) \\
N=13\end{array}$ & $\begin{array}{c}19.0^{\mathrm{a}} \\
( \pm 2 \cdot 0) \\
\mathrm{N}=18\end{array}$ & $\begin{array}{c}25 \cdot 5^{\mathrm{a}} \\
( \pm 5 \cdot 4) \\
\mathrm{N}=18\end{array}$ & $20 \cdot 97^{* *}$ \\
\hline Ejaculate 1 & $\begin{array}{c}17 \cdot 1^{\text {a.x }} \\
( \pm 3 \cdot 3) \\
N=13\end{array}$ & $\begin{array}{c}2 \cdot 0^{\mathrm{b} . x} \\
( \pm 0 \cdot 5) \\
\mathrm{N}=13\end{array}$ & $\begin{array}{c}10 \cdot 2^{\mathrm{a} \cdot \mathrm{x}} \\
( \pm 1 \cdot 1) \\
\mathrm{N}=18\end{array}$ & $\begin{array}{c}13 \cdot 2^{\mathbf{a}, \mathbf{x}} \\
( \pm 2 \cdot 5) \\
\mathrm{N}=18\end{array}$ & $18.05^{* *}$ \\
\hline Ejaculate 2 & $\begin{array}{c}11 \cdot 3^{\text {a.y }} \\
( \pm 2 \cdot 8) \\
N=13\end{array}$ & $\begin{array}{c}1 \cdot 2^{b . y} \\
( \pm 0 \cdot 5) \\
N=11\end{array}$ & $\begin{array}{c}5 \cdot 4^{a . y} \\
( \pm 1 \cdot 8) \\
N=17\end{array}$ & $\begin{array}{r}9 \cdot 5^{\mathrm{a} \cdot \mathrm{y}} \\
( \pm 2 \cdot 8) \\
\mathrm{N}=12\end{array}$ & $12 \cdot 49^{* * *}$ \\
\hline Ejaculate 3 & $\begin{array}{c}3 \cdot 2^{\mathrm{a}, \mathrm{z}} \\
( \pm 2 \cdot 0) \\
\mathrm{N}=8\end{array}$ & $\begin{array}{c}0.6^{a, y} \\
( \pm 0.2) \\
\mathrm{N}=5\end{array}$ & $\begin{array}{c}4 \cdot 4^{\text {a.y }} \\
( \pm 0 \cdot 4) \\
\mathrm{N}=12\end{array}$ & $\begin{array}{c}9 \cdot 5^{\text {b,y }} \\
( \pm 2 \cdot 8) \\
N=8\end{array}$ & $7 \cdot 83^{*}$ \\
\hline Ejaculate 4 & & $\begin{array}{c}0.1 \\
( \pm 0 \cdot 1) \\
\mathrm{N}=2\end{array}$ & $\begin{array}{c}0.9^{-. z} \\
( \pm 1.4) \\
\mathrm{N}=10\end{array}$ & $\begin{array}{l}5 \cdot 8^{-. y} \\
( \pm 2 \cdot 3) \\
N=5\end{array}$ & \\
\hline Ejaculate 5 & & & $\begin{array}{c}1 \cdot 5 \\
( \pm 1 \cdot 4) \\
N=3\end{array}$ & $\begin{array}{c}0.04 \\
\stackrel{-}{-}) \\
N=1\end{array}$ & \\
\hline Ejaculate 6 & & & $\begin{array}{l}0.0 \\
(-)\end{array}$ & $\begin{array}{l}1 \cdot 7 \\
(-)\end{array}$ & \\
\hline Ejaculate 7 & & & $\begin{array}{c}\mathrm{N}=1 \\
0 \cdot 2 \\
(-) \\
\mathrm{N}=1\end{array}$ & $N=1$ & \\
\hline
\end{tabular}

Values are mean $( \pm$ s.e.m).

${ }^{*} P<0.05 ;{ }^{* *} P<0.01$.

Superscript letters indicate the results of pairwise comparisons. The first letter of each pair ( $a$ or $b$ ) indicates the results of Mann-Whitney $U$ comparisons between species and are read across a row. Means with different letters differ significantly. The second letter of each pair ( $x, y$ or $z$ ) indicates the results of Wilcoxon matched-pairs signed-ranks tests for changes in sperm counts in successive ejaculates within a species and are read down a column. Means with different letters differ significantly.

Species differences reached statistical significance for total number of spermatozoa ejaculated and number of spermatozoa ejaculated in each of the first three ejaculates, but not for number of ejaculations (see Table 1). The statistical significance of species differences in total number of spermatozoa ejaculated was due largely to pine voles, which ejaculated significantly fewer spermatozoa than any of the other species. Pine voles also delivered significantly fewer spermatozoa per ejaculate than any of the other species for the 1 st and 2 nd ejaculates. Sperm numbers for the 3 rd ejaculate were significantly greater for meadow voles than prairie, montane, or pine voles. For all species, appreciable and significant decrements in sperm counts across successive ejaculates were noted (see Table 1).

\section{Testes mass}

Data on body and testes masses for the 4 species are presented in Table 2 . The 4 species differed significantly with respect to all measures of body and testes mass. Significant differences in pairwise comparisons were noted for all testes measurements, with meadow voles having the largest testes and greatest testes/body ratio and pine voles having the smallest testes and testes/body ratio. 
Table 2. Measures of body and testes mass in 4 species of voles

\begin{tabular}{|c|c|c|c|c|c|}
\hline Measure & $\begin{array}{c}\text { Prairie } \\
\text { voles } \\
(N=13)\end{array}$ & $\begin{array}{c}\text { Pine } \\
\text { voles } \\
(N=15)\end{array}$ & $\begin{array}{c}\text { Montane } \\
\text { voles } \\
(\mathrm{N}=12)\end{array}$ & $\begin{array}{c}\text { Meadow } \\
\text { voles } \\
(N=17)\end{array}$ & $F$ \\
\hline Body mass (g) & $\begin{array}{r}45 \cdot 4^{\mathrm{a}} \\
( \pm 1 \cdot 2)\end{array}$ & $\begin{array}{r}20 \cdot 1^{\mathrm{b}} \\
( \pm 0 \cdot 9)\end{array}$ & $\begin{array}{r}43 \cdot 0^{a} \\
( \pm 1 \cdot 8)\end{array}$ & $\begin{array}{r}54 \cdot 6^{\circ} \\
( \pm 2 \cdot 3)\end{array}$ & $97.01^{*}$ \\
\hline Testes mass ( $\mathrm{g}$ ) & $\begin{array}{c}0.52^{\mathrm{a}} \\
( \pm 0.04)\end{array}$ & $\begin{array}{c}0.07^{\mathrm{b}} \\
( \pm 0.003)\end{array}$ & $\begin{array}{c}0.38^{\mathrm{c}} \\
( \pm 0.02)\end{array}$ & $\begin{array}{r}1 \cdot 17^{\mathrm{d}} \\
( \pm 0 \cdot 1)\end{array}$ & $122 \cdot 78^{*}$ \\
\hline Left testis ( $\mathrm{g}$ ) & $\begin{array}{c}0.26^{\mathrm{a}} \\
( \pm 0.02)\end{array}$ & $\begin{array}{c}0.03^{\mathrm{b}} \\
( \pm 0.002)\end{array}$ & $\begin{array}{c}0.19^{c} \\
( \pm 0.01)\end{array}$ & $\begin{array}{c}0.58^{\mathrm{d}} \\
( \pm 0.04)\end{array}$ & $107 \cdot 11^{*}$ \\
\hline Right testis (g) & $\begin{array}{c}0.26^{\mathbf{a}} \\
( \pm 0.02)\end{array}$ & $\begin{array}{c}0.03^{\mathrm{b}} \\
( \pm 0.002)\end{array}$ & $\begin{array}{c}0.19^{c} \\
( \pm 0.01)\end{array}$ & $\begin{array}{c}0.59^{\mathrm{d}} \\
( \pm 0.04)\end{array}$ & $135 \cdot 46^{*}$ \\
\hline Testes/body ratio & $\begin{array}{r}1 \cdot 16^{\mathrm{a}} \\
( \pm 0.09)\end{array}$ & $\begin{array}{r}0.33^{\mathrm{b}} \\
( \pm 0.02)\end{array}$ & $\begin{array}{c}0.88^{\mathrm{a}} \\
( \pm 0.03)\end{array}$ & $\begin{array}{c}2 \cdot 19^{\mathrm{c}} \\
( \pm 0.20)\end{array}$ & $60 \cdot 23^{*}$ \\
\hline
\end{tabular}

Values are mean ( \pm s.e.m).

${ }^{*} P<0.001$.

Superscript letters indicate the results of Newman-Keuls pairwise comparisons and are read across a row. Means with different letters differ significantly.

\section{Discussion}

A critical, but rarely tested, assumption in recent comparative analyses (e.g. Short, 1979; Kenagy \& Trombulak, 1986) has been that species differences in testes sizes reflect species differences in the number of spermatozoa actually in ejaculates delivered to females. The present data suggest such a relationship. Significant across-species differences were noted for both these variables and larger absolute testes sizes were associated with more spermatozoa. Testes measurements were generally in the range of values reported previously (prairie voles: Nelson, 1985a, b; meadow voles: Dietrich et al., 1973; Imel \& Amann, 1979). The values obtained for montane voles are somewhat larger than those reported for field-trapped animals by Berger et al. (1981).

No simple, consistent relationship emerges among mating system, testes size, and number of spermatozoa ejaculated. Data from pine voles are consistent with the suggested pattern; this monogamous species has small testes, a small testes/body ratio, and greatly reduced sperm numbers. However, prairie voles, the other monogamous species studied, have relatively large testes and ejaculated the greatest number of spermatozoa. Likewise, data from the 2 polygamous species are inconsistent with the hypothesis, with meadow voles generally fitting the predicted pattern of large testes and great sperm numbers, whereas montane voles have intermediate sperm numbers and small testes.

The absence of a consistent relationship is somewhat surprising. However, the critical variable may not be mating system per se, but rather the occurrence of multiple-male mating by a single female during a single receptive period. The available evidence suggests that meadow voles display multiple-male mating (Madison, 1980a, b), whereas pine (FitzGerald \& Madison, 1983) and prairie (Getz \& Hofmann, 1986) voles do not. Multiple-male mating has yet to be demonstrated in montane voles in the field. Wolff $(1985)$ has proposed that, although female montane voles do not form a monogamous pair bond, they "apparently mate with only one familiar male" (p. 348). If Wolff (1985) is correct, a stronger relationship emerges. It appears not to be the formation of a pair bond that is critical for the evolution of sperm numbers, but the number of males mating with the oestrous female (see discussion of monogamy in Dewsbury, 1988). This is illustrated in the work of Harvey \& Harcourt (1984) in which the relative canine size of primates was related to the number of males in the troop but testes size was related instead to the number of males actually copulating 
with females. Testes size, number of ejaculations, and number of spermatozoa per ejaculate in birds may also be affected by the possibility of multiple mating by females (Moller, 1988b).

All 4 species of voles in the present study showed significant decreases in the number of spermatozoa across successive ejaculates, with over $50 \%$ of total sperm output delivered in the first ejaculate in each of the 4 species. A tentative classification based on Parker's (1984) S vs M pattern is difficult. Each species shows the large initial ejaculate characteristic of an S-like pattern, with significant decrements in sperm number across all ejaculates produced. However, meadow voles showed flatter functions of sperm counts over successive ejaculates (see Table 1) with no significant difference in sperm number noted among the 2 nd, 3rd and 4th ejaculates. Therefore, while size of the initial ejaculate is consistent with an S-like pattern for each species, the pattern of sperm numbers in subsequent ejaculates suggests an S-like pattern for prairie, montane and pine voles, and an M-like pattern for meadow voles. Only montane voles fail to fit the hypothesis that monogamous species should display an S-like pattern and polygamous species an M-like pattern; a discrepancy possibly attributed to the absence of multiple mating by this species (see discussion above).

These data on 4 species of voles can be combined with those on deer mice, Peromyscus maniculatus (Dewsbury \& Sawrey, 1984) and laboratory rats, Rattus norvegicus (Austin \& Dewsbury, 1986) for comparative analysis of 6 species of muroid rodents studied under similar conditions in one laboratory. Selected measures of morphology and sperm production are compared in Table 3.

Table 3. Morphological characteristics related to sperm production and allocation in 6 species of muroid rodents

\begin{tabular}{|c|c|c|c|c|c|c|}
\hline \multirow[b]{2}{*}{ Measure } & \multicolumn{6}{|c|}{ Species } \\
\hline & $\begin{array}{c}\text { Prairie } \\
\text { voles }\end{array}$ & $\begin{array}{c}\text { Montane } \\
\text { voles }\end{array}$ & $\begin{array}{l}\text { Pine } \\
\text { voles }\end{array}$ & $\begin{array}{c}\text { Meadow } \\
\text { voles }\end{array}$ & $\begin{array}{l}\text { Deer } \\
\text { mice }\end{array}$ & $\begin{array}{c}\text { Laboratory } \\
\text { rats }\end{array}$ \\
\hline Body mass (g) & $45 \cdot 4$ & $43 \cdot 0$ & $20 \cdot 1$ & $54 \cdot 6$ & $19 \cdot 5$ & $500 \cdot 0$ \\
\hline Testes mass (g) & 0.52 & 0.38 & 0.07 & $1 \cdot 17$ & $0 \cdot 39$ & $4 \cdot 0$ \\
\hline Testes/body mass $\times 100$ & $1 \cdot 16$ & $0 \cdot 88$ & 0.33 & $2 \cdot 19$ & $2 \cdot 00$ & $0 \cdot 80$ \\
\hline No. of ejaculations/episode & $2 \cdot 0$ & $5 \cdot 0$ & $2 \cdot 4$ & $2 \cdot 5$ & $3 \cdot 6$ & $7 \cdot 0$ \\
\hline Total spermatozoa/episode $\left(\times 10^{-6}\right)$ & $30 \cdot 5$ & $19 \cdot 0$ & $3 \cdot 3$ & $25 \cdot 5$ & $47 \cdot 8$ & 143.0 \\
\hline Sperm no. in lst ejaculate $\left(\times 10^{-6}\right)$ & $17 \cdot 1$ & $10 \cdot 2$ & $2 \cdot 0$ & $13 \cdot 2$ & $17 \cdot 0$ & $30 \cdot 7$ \\
\hline Sperm no. in 3 rd ejaculate $\left(\times 10^{-6}\right)$ & $3 \cdot 2$ & $4 \cdot 4$ & 0.6 & $9 \cdot 5$ & $9 \cdot 8$ & $30 \cdot 4$ \\
\hline Sperm no. in $3 \mathrm{rd} / \mathrm{l}$ st ejaculate & $0 \cdot 19$ & $0 \cdot 42$ & $0 \cdot 30$ & 0.72 & 0.58 & 0.99 \\
\hline Sperm no./testes mass* & $58 \cdot 6$ & $50 \cdot 0$ & $47 \cdot 1$ & $21 \cdot 8$ & $122 \cdot 7$ & $35 \cdot 8$ \\
\hline Total sperm length $(\mu \mathrm{m})$ & $94 \cdot 4$ & - & - & - & $75 \cdot 0$ & 188.7 \\
\hline
\end{tabular}

Data are from the present study, Austin (1986), Cummins \& Woodall (1985), Dewsbury (1981), and Kenagy \& Trombulak (1986).

*Total no. of spermatozoa divided by testes mass.

Allometric relationships are quite apparent. Large body mass in this sample is associated with large testes sizes and large numbers of spermatozoa. On the other hand, the testes/body mass ratios are generally inversely related to other measures, such as body mass. This is consistent with the analysis of morphological data of a wider sample of mammalian species by Kenagy \& Trombulak (1986), who noted that "Smaller mammals must allocate a greater proportion of body mass and of energy expenditure to testicular tissue than larger mammals" (p. 1). Rodent species generally fit this pattern, although exceptions (e.g. males of the genera Notomys and Pseudomys: Breed, 1982; Kenagy \& Trombulak, 1986) have been noted. 
Mating by single females with multiple males appears quite common in laboratory rats (see Barnett, 1958; Robitaille \& Bovet, 1976) and deer mice (Birdsall \& Nash, 1973). The large testes mass of laboratory rats and the large relative testes mass of deer mice appear reasonable in view of such multiple mating. Which of these morphological measures will prove more useful in the long term in this context should be revealed as additional species are studied.

Patterns of change in sperm counts across successive ejaculates in different species are most clear when the data are expressed as a percentage of the first-ejaculate values, so as to remove absolute differences. These patterns are indicated in Fig. 1. Clearly, the slope of the function relating sperm numbers to ejaculates is sharpest for prairie, montane and pine voles. By comparison, the slope of the function is relatively flat for the 3 species (meadow voles, laboratory rats and deer mice) in which multiple mating appears common. Indeed, in rats there is a slight increase in the number of spermatozoa ejaculated from the 1 st to the 2 nd ejaculate. Toner \& Adler (1985) found sperm numbers in older male rats to peak in the 3rd series.

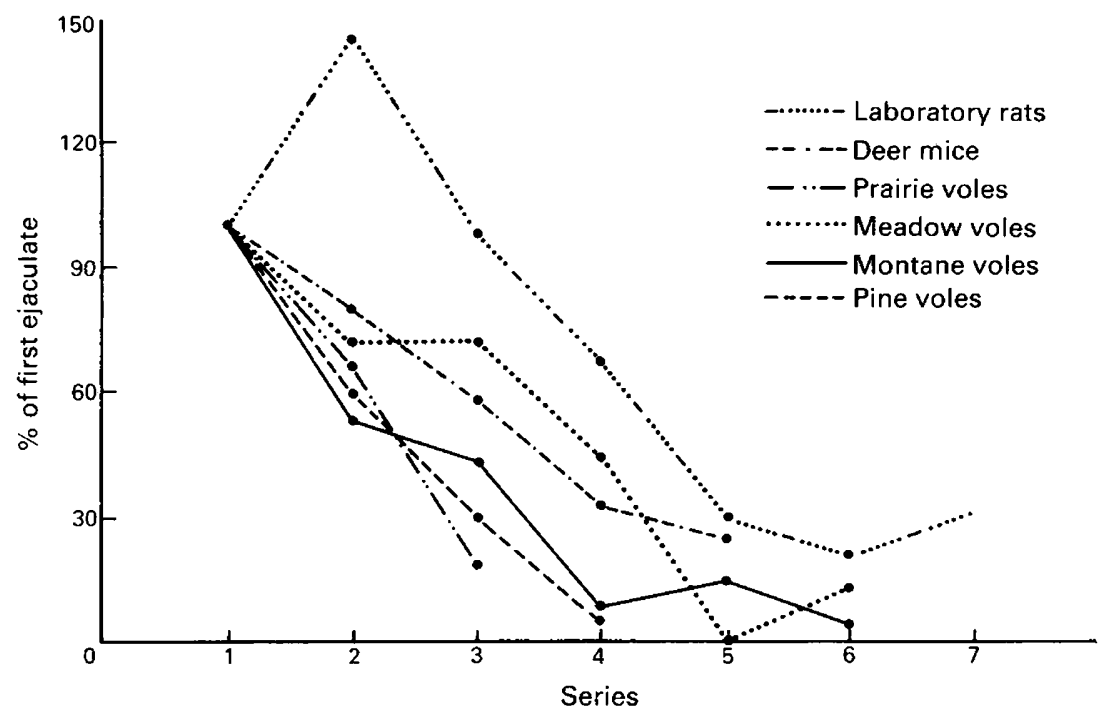

Fig. 1. Changes in mean sperm counts, expressed in relation to the first ejaculate, in samples taken from successive females across successive ejaculates of males from 6 species of muroid rodents. Data are from the present study and those of Austin \& Dewsbury (1986) and Dewsbury \& Sawrey (1984).

Several other factors should be considered. Information on the potency of the late ejaculates in the four Microtus species is lacking. Species seem to differ in this respect, with the late ejaculates of rats (Toner \& Adler, 1985; Austin \& Dewsbury, 1986), and golden hamsters (Huck \& Lisk, 1985) being of reduced potency, whereas those of rabbits (Adams \& Singh, 1981) and deer mice (Dewsbury \& Sawrey, 1984) show no such apparent decline. It has been estimated that the potency of male house mice is not decreased until epididymal sperm counts decrease to $10 \%$ of baseline (Searle \& Beechey, 1974). Secondly, data are needed on changes in constituents of ejaculates other than spermatozoa (see Pessah \& Kochva, 1975; Adams \& Singh, 1981; Bakst \& Cecil, 1981). Finally, in addition to the course of depletion of sperm resources, more data on the rate of recovery to baseline levels are needed (see Dewsbury \& Sawrey, 1984; Austin, 1986).

This research was supported by grants BNS-8520318 and BNS-8904974 from the National Science Foundation. We thank two anonymous reviewers for helpful comments. 


\section{References}

Abdou, M.S.S., Hassun, T.M. \& El-Sawaf, S.A. (1978) Testicular and epididymal sperm numbers and related parameters in the developing Awassi ram. Aust. J. biol. Sci. 31, 257-266.

Adams, C.E. \& Singh, M.M. (1981) Semen characteristics and fertility of rabbits subjected to exhaustive use. Lab. Anim. 15, 157-161.

Austin, D. (1986) Reproductive capacity of male laboratory rats. Doctoral dissertation, University of Florida.

Austin, D. \& Dewsbury, D.A. (1986) Reproductivecapacity of male laboratory rats. Physiol. Behav. 37, 627-632.

Bakst, M.R. \& Cecil, H.C. (1981) Changes in the characteristics of turkey ejaculated semen and ductus deferens semen with repeated ejaculations. Reprod. Nutr. Develop. 21, 1095-1103.

Barnett, S.A. (1958) An analysis of social behaviour in wild rats. Proc. zool. Soc. Lond. 130, 107-152.

Berger, P.J., Negus, N.C., Sanders, E.H. \& Gardner, P.D. (1981) Chemical triggering of reproduction in Microtus montanus. Science, NY 214, 69-70.

Birdsall, D.A. \& Nash, D. (1973) Occurrence of successful multiple insemination of females in natural populations of deer mice (Peromyscus maniculatus). Evalution 27, 106-110.

Breed, W.G. (1982) Morphological variation in the testes and accessory sex organs of Australian rodents in the genera Pseudomys and Notomys. J. Reprod. Fert. 66, 607-613.

Carter, A.P., Wood, P.D.P. \& Wright, P.A. (1980) Association between scrotal circumference, live weight and sperm output in cattle, J. Reprod. Fert. 59, 447-451.

Carter, C.S., Getz, L.L., Gavish, L., McDermott, J.L. \& Arnold, P. (1980) Male-related pheromones and the activation of female reproduction in the prairie vole (Microtus ochrogaster). Biol. Reprod. 23, $1038-1045$.

Carter, C.S., Getz, L.L. \& Cohen-Parsons, M. (1986) Relationships between social organization and behavioural endocrinology in a monogamous mammal. Adv. Stud. Behav. 16, 109-145.

Clutton-Brock, T.H., Guinness, F.E. \& Albon, S.D. (1982) Red Deer: Behavior and Ecology of Two Sexes. University of Chicago Press, Chicago.

Cummins, J.M. \& Woodall, P.F. (1985) On mammalian sperm dimensions. J. Reprod. Fert. 75, 153-175.

Dewsbury, D.A. (1973) Copulatory behaviour of montane voles (Microtus montanus). Behaviour 44, 186-202.

Dewsbury, D.A. (1981) An exercise in the prediction of monogamy in the field from laboratory data on 42 species of muroid rodents. Biologist 63, 138-162.

Dewsbury, D.A. (1982) Ejaculate cost and male choice. Am. Nat. 119, 601-610.

Dewsbury, D.A. (1988) The comparative psychology of monogamy. Nebraska Symp. Motiv. 35, 1-50.

Dewsbury, D.A. \& Sawrey, D.K. (1984) Male capacity as related to sperm production, pregnancy initiation, and sperm competition in deer mice (Peromyscus maniculatus). Behav. Ecol. Sociobiol. 16, 37-47.

Dickinson, J.L. (1986) Prolonged mating in the milkweed leaf beetle Labidomera clavicollis clavicollis (Coleop- tera: Chrysomelidae): a test of the "sperm-loading" hypothesis. Behav. Ecol. Sociobiol. 18, 331-338.

Dietrich, R.A., Morrison, P.R. \& Preston, D.J. (1973) Comparative organ weights for 8 standardized wild rodent species. Lab. Anim. Sci. 23, 575-581.

FitzGerald, R.W. \& Madison, D.M. (1983) Social organization of a free-ranging population of pine voles, Microtus pinetorum. Behav. Ecol. Sociobiol. 13, 183-187.

Getz, L.L. \& Hofmann, J.E. (1986) Social organization in free-living prairie voles, Microtus ochrogaster. Behav. Ecol. Sociobiol. 18, 275-282.

Getz, L.L., Carter, C.S. \& Gavish, L. (1981) The mating system of the prairie vole, Microtus ochrogaster: field and laboratory evidence for pair-bonding. Behav. Ecol. Sociobiol. 8, 189-194.

Gibson, R.M. \& Jewell, P.A. (1982) Semen quality, female choice and multiple mating in domestic sheep: a test of Trivers' sexual competence hypothesis. Behaviour 80, 9-31.

Gray, G.D. \& Dewsbury, D.A. (1973) A quantitative description of copulatory behavior in prairie voles (Microtus ochrogaster). Brain. Behav. Evol. 8, $437-452$.

Harcourt, A.H., Harvey, P.H., Larson, S.G. \& Short, R.V. (1981) Testis weight, body weight and breeding system in primates. Nature, Lond. 293, 55-57.

Harvey, P.H. \& Harcourt, A.H. (1984) Sperm competition, testes size, and breeding systems in primates. In Sperm Competition and the Evolution of Animal Mating Systems, pp. 589-600. Ed. R. L. Smith. Academic Press, New York.

Harvey, P.H. \& May, R.M. (1989) Out for the sperm count. Nature, Lond. 337, 508-509.

Huck, U.W. \& Lisk, R.D. (1985) Determinants of mating success in the golden hamster (Mesocricetus auratus). II. Pregnancy initiation. J.comp. Physiol. 99, 231-239.

Imel, K.J. \& Amann, R.P. (1979) Effects of duration of daily illumination on reproductive organs and fertility of the meadow vole (Microtus pennsy/vanicus). Lab. Anim. Sci. 29, 182-185.

Jannett, F.J. (1980) Social dynamics of the montane vole, Microtus montanus, as a paradigm. Biologist 62, 3-19.

Jannett, F.J. (1982) Nesting patterns of adult voles, Microtus montanus, in field populations. J. Mammal. 63, 495-498.

Kenagy, G.J. \& Trombulak, S.C. (1986) Size and function of mammalian testes in relation to body size. $J$. Mammal. 67, 1-22.

King, J.A. (1970) Ecological psychology: an approach to motivation. Nebraska Symp. Motiv. 18, 1-33.

Kleiman, D.G. (1977) Monogamy in mammals. Q. Rev. Biol. 52, 39-69.

Lanier, D.L., Estep, D.Q. \& Dewsbury, D.A. (1979) Role of prolonged copulatory behavior in facilitating reproductive success in a competitive mating situation in laboratory rats. J. comp. Physiol. Psychol. 93, 781-792

Lino, B.F. (1972) The output of spermatozoa in rats. II. Relationship to scrotal circumference, testis weight, and the number of spermatozoa in different parts of the urogenital tract. Aust. J. biol. Sci. 25, 351-358. 
Lott, D.F. (1981) Sexual behavior and intersexual strategies in American bison. Z. Tierpsychol. 56, 97-114.

Madison, D.M. (1980a) An integrated view of the social biology of Microtus pennsylvanicus. Biologist 62, 20-33.

Madison, D.M. (1980b) Space use and social structure in meadow voles, Microtus pennsylvanicus. Behav. Ecol. Sociobiol. 7, 65-71.

Markow, T.A. (1985) A comparative investigation of the mating system of Drosophila hydei. Anim. Behav. 33, $775-781$.

Moller, A.P. (1988a) Ejaculate quality, testes size and sperm competition in primates. J. human Evol. 17, 479-488.

Moller, A.P. (1988b) Testes size, ejaculate quality and sperm competition in birds. Biol. J. Linn. Soc. 33, $272-283$.

Moller, A.P. (1989) Ejaculate quality, testes size and sperm production in mammals. Funct. Ecol. 3, 91-96.

Nelson, R.J. (1985a) Photoperiodic regulation of reproductive development in male prairie voles: influence of laboratory breeding. Biol. Reprod. 33, 418-422.

Nelson, R.J. (1985b) Photoperiod influences reproduction in the prairie vole (Microtus ochrogaster). Biol. Reprod. 33, 596-602.

Parker, G.A. (1970) Sperm competition and its evolutionary consequences in the insects. Biol. Rev. 45, 525-567.

Parker, G.A. (1984) Sperm competition and the evolution of animal mating strategies. In Sperm Competition and the Evolution of Animal Mating Systems, pp. I-60. Ed. R. L. Smith. Academic Press, New York.
Pessah, H. \& Kochva, E. (1975) The secretory activity of the seminal vesicles in the rat after copulation. Biol. Reprod. 13, 557-560.

Robitaille, J.A. \& Bovet, J. (1976) Field observations on the social behaviour of the Norway rat, Rattus norvegicus (Berkenhout). Biol. Behav. 1, 289-308.

Rowsemitt, C.N., Petterborg, L.J., Claypool, L.E., Hoppenstaedt, F.C., Negus, N.C. \& Berger, P.J. (1982) Photoperiodic induction of diurnal locomotor activity in Microtus montanus, the montane vole. Can. J. Zool. 60, 2798-2803.

Sawrey, D.K. \& Dewsbury, D.A. (1985) Control of ovulation, vaginal estrus, and behavioral receptivity in voles (Microtus). Neurosc. Biobeh. Reviews 9, 563-571.

Searle, A.G. \& Beechey, C.V. (1974) Sperm-count, eggfertilization and dominant lethality after $\mathrm{x}$-irradiation of mice. Mut. Res. 22, 63-72.

Short, R.V. (1979) Sexual selection and its component parts, somatic and genital selection, as illustrated by man and the great apes. Adv. Stud. Behav. 9, 131-158.

Squires, E.L., Pickett, B.W. \& Amann, R.P. (1979) Effect of successive ejaculation on stallion seminal characteristics. J. Reprod. Fert., Suppl. 27, 7-12.

Svard, L. \& Wiklund, C. (1986) Different ejaculate delivery strategies in first versus subsequent matings in the swallowtail butterfly Papilio machaon L. Behav. Ecol. Sociobiol. 18, 325-330.

Toner, J.P. \& Adler, N.T. (1985) Potency of rat ejaculations varies with their order and with male age. Physiol. Behav. 35, 113-115.

Wolff, J.O. (1985) Behavior. In Biology of New World Microtus, pp. 340-372. Ed. R. H. Tamarin. American Society of Mammalogists, Lawrence, KS.

Received 22 March 1989 